\title{
AUTONOMIC NERVOUS SYSTEM AND OVIDUCT FUNCTION IN THE RABBIT
}

\section{HORMONES AND CONTRACTION}

\author{
G. R. HOWE AND D. L. BLACK \\ Laboratory for Reproductive Physiology, Department of Veterinary and Animal Science, \\ University of Massachusetts, Amherst, Massachusetts 01002, U.S.A.
}

(Received 27th April 1972)

\begin{abstract}
Summary. Resistance to perfusion of the oviducal isthmus in anaesthetized rabbits was enhanced by adrenaline and depressed by isoprenaline. Ovariectomy significantly decreased the response of the oviducal musculature to both autonomic drugs. The degree of response of adrenergic alpha and beta receptors was primarily dependent upon oestrogen and progesterone, respectively. Increased spontaneous activity of the tubal musculature following ovariectomy appeared to be related to oestrogen withdrawal.
\end{abstract}

\section{INTRODUCTION}

The significance of oviducal muscular activity in ovum transport remains controversial (Blandau, 1969). Ovulated eggs are rapidly transported to the ampullary-isthmic junction (Harper, 1966) and then slowly migrate through the isthmus into the uterus (Longley \& Black, 1968; Howe, 1970). Sphincteric activity at the ampullary-isthmic junction or uterotubal junction as well as isthmic tonus have been implicated in the synchronized pattern of ovum transport (Black \& Asdell, 1958; Greenwald, 1961).

Oestrogens and progestins have been recognized as playing an essential rôle in normal tubal transport (Chang \& Harper, 1966; Harper, 1966). In general, oestrogens are thought to stimulate while progestins repress oviducal contractility. More recently, however, studies by Boling \& Blandau (1971) suggest that ampullary contractions increase as the oestrogen decreases. Contradictory opinions concerning the rôle of ovarian hormones in controlling the rate of egg transport have been summarized elsewhere (Boling, 1969).

Rosenblum \& Stein (1966) demonstrated the presence of alpha and beta adrenergic receptors in the circular muscle of human oviducts. Studies by Brundin (1965) showed that stimulation of the hypogastric nerves increased the opening pressure of the tubal isthmus, whereas blocking alpha adrenergic receptors with phentolamine decreased the opening pressure. The injection of noradrenaline and adrenaline into anaesthetized rabbits initiates contraction of the oviduct, while isoprenaline relaxes the tubal musculature (Longley, Black \& Currie, 1968a). The action of adrenaline and isoprenaline is blocked 
by phenoxybenzamine and propranolol, respectively. Additional studies by Longley $e t$ al. (1968b) show that phenoxybenzamine effectively inhibits the movement of ova through the oviduct, but the relationship between the ovarian hormones and autonomic drugs is not clear.

The research presented here was conducted to determine if an interaction between the ovarian hormones and the adrenergic nervous system exists. The studies evaluate adrenergic-hormonal interaction in terms of their effect on oviduct contractility.

\section{MATERIALS AND METHODS}

Sexually mature New Zealand does were anaesthetized with Nembutal and subjected to laparotomy. Polyethylene tubing (PE 90; i.d. 0.034 in., o.d. 0.050 in.) was inserted into the lumen of the tubal isthmus and directed towards the uterus so that a $10-\mathrm{mm}$ segment of the oviduct was perfused. The PE tubing was connected to a constant-rate perfusion pump (Harvard Apparatus) and pressure transducer (Statham P23AA). Muscular activity was recorded with a Beckman Dynograph Recorder equipped with a Resetting Integrating Coupler. The latter measured the area $\left(\mathrm{cm}^{2}\right)$ under the pressure curve. Sterile saline $(0.9 \%)$ was perfused at a rate of $100 \mu \mathrm{l} / \mathrm{min}$.

Three doses of adrenaline (Wolins; $2.5,5.0$ and $7.5 \mu \mathrm{g} / \mathrm{kg}$ ) and isoprenaline (Winthrop, Isoprel; $1.0,2.0$ and $4.0 \mu \mathrm{g} / \mathrm{kg}$ ) were injected into the marginal ear vein on a randomized duplicate basis. More specifically, the six injections of adrenaline were followed by six doses of isoprenaline with a 10-min interval between all injections. The data were evaluated by comparing the area $\left(\mathrm{cm}^{2}\right)$ under the pressure curves for the 3-min interval just before and after drug administration. This procedure was utilized for the following experimental groups: (A) does mated $1 \mathrm{hr}$ before perfusion; (B) ovariectomy 21 to 28 days before perfusion; (C) oestrogen (17 $\beta$-oestradiol 17-cyclopentylpropionate) in oil, $25 \mu \mathrm{g} / \mathrm{kg}$ subcutaneously $48 \mathrm{hr}$ before perfusion; (D) progesterone in oil, $1 \mathrm{mg} /$ day subcutaneously for 5 days before perfusion; and (E) oestrogen on Day 1, progesterone on Days 2 to 6, and perfusion on Day 7. The hormone treatments in Groups C, D and $\mathbf{E}$ were initiated 21 days after ovariectomy.

\section{RESULTS}

The perfusion of the tubal isthmus above the uterotubal junction revealed fluctuations in the rate and amplitude of contractile waves. Because of contractile variations, the activity of the musculature was quantified in terms of area $\left(\mathrm{cm}^{2}\right)$ under the pressure curve. The mean spontaneous activity of the isthmic musculature remained above control levels for up to 28 days after ovariectomy (Table 1). The administration of oestrogen suppressed oviducal activity whereas progesterone increased the perfusion resistance. The combined treatment with both hormones provided a perfusion pressure pattern similar to that observed in control animals.

The intravenous injection of adrenaline initiated a tubal contraction that was sustained for 2 to $3 \mathrm{~min}$. As shown in Text-fig. 1, there was a distinct dose- 
Table 1. The influence of adrenaline and isoprenaline on oviduct contractions of hormone-treated rabbits

\begin{tabular}{|c|c|c|c|c|c|c|c|}
\hline \multirow{3}{*}{ Treatment before perfusion } & \multicolumn{7}{|c|}{ Mean area under the curve $\left(\mathrm{cm}^{2}\right)$} \\
\hline & \multirow{2}{*}{$\begin{array}{c}\text { Pre- } \\
\text { treatment }\end{array}$} & \multicolumn{3}{|c|}{ Adrenaline } & \multicolumn{3}{|c|}{ Isoprenaline } \\
\hline & & $2.5 \mu g / k g$ & $5 \cdot 0 \mu \mathrm{g} / \mathrm{kg}$ & $7 \cdot 5 \mu g / k g$ & $1.0 \mu g / k g$ & $2 \cdot 0 \mu \mathrm{g} / \mathrm{kg}$ & $4.0 \mu \mathrm{g} / \mathrm{kg}$ \\
\hline $\begin{array}{l}\text { A. Does mated } 1 \mathrm{hr} \text { before } \\
\text { (Five animals) }\end{array}$ & $13 \cdot 38$ & $+11 \cdot 27$ & $+13 \cdot 67$ & $+16 \cdot 80$ & -1.74 & -1.89 & $-3 \cdot 06$ \\
\hline $\begin{array}{l}\text { B. Ovariectomy } 21 \text { to } 28 \\
\text { days before } \\
\text { (Seven animals) }\end{array}$ & $19 \cdot 07$ & $+6 \cdot 48$ & $+7 \cdot 80$ & +11.74 & -1.03 & -1.57 & $-2 \cdot 49$ \\
\hline $\begin{array}{l}\text { G. Ovariectomy } 21 \text { days } \\
\text { before, followed by } \\
\text { oestrogen for } 48 \mathrm{hr} \text { before } \\
\text { (Five animals) }\end{array}$ & $7 \cdot 91$ & $+12 \cdot 70$ & $+15 \cdot 18$ & $+18 \cdot 48$ & $-1 \cdot 26$ & -1.88 & $-2 \cdot 29$ \\
\hline $\begin{array}{l}\text { D. Ovariectomy } 21 \text { days } \\
\text { before, followed by pro- } \\
\text { gesterone for } 5 \text { days } \\
\text { before (Six animals) }\end{array}$ & $17 \cdot 74$ & +6.53 & $+9 \cdot 33$ & $+12 \cdot 22$ & $-1 \cdot 47$ & $-2 \cdot 08$ & $-2 \cdot 68$ \\
\hline $\begin{array}{l}\text { E. Ovariectomy } 21 \text { days } \\
\text { before, followed by } \\
\text { oestrogen for } 1 \text { day and } \\
\text { progesterone for } 5 \text { days } \\
\text { before (Six animals) }\end{array}$ & $13 \cdot 85$ & $+14 \cdot 70$ & $+15 \cdot 61$ & +20.72 & -1.92 & $-2 \cdot 33$ & $-3 \cdot 97$ \\
\hline
\end{tabular}

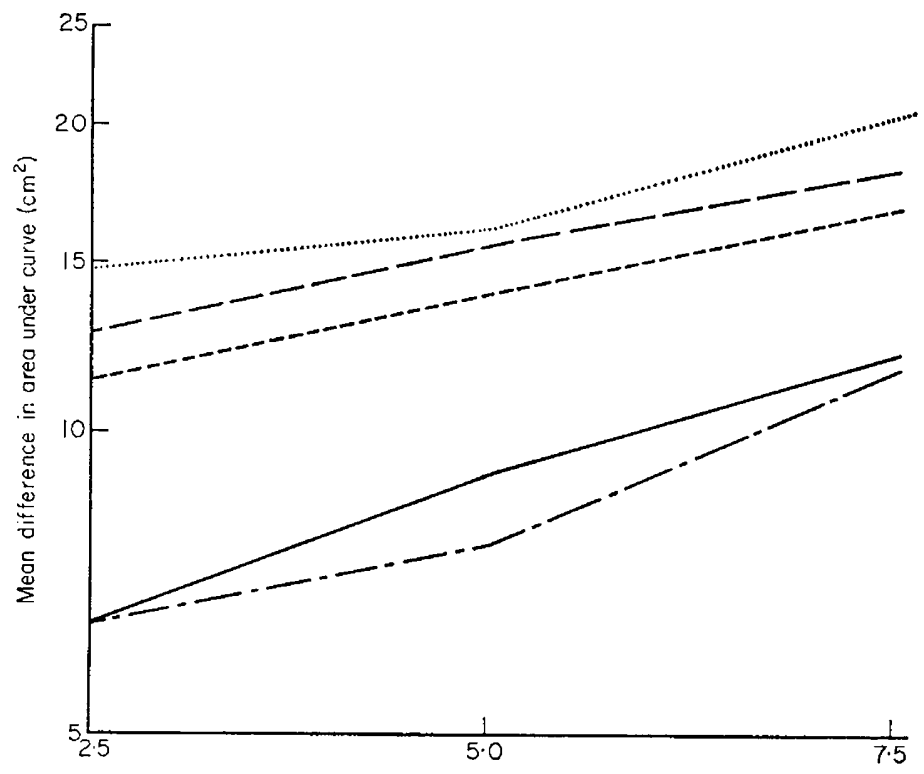

$\mu \mathrm{g}$ adrenoline $/ \mathrm{kg}$ body weight

TexT-FIG. 1. Ghanges in area under curve for oviduct tracings caused by adrenaline

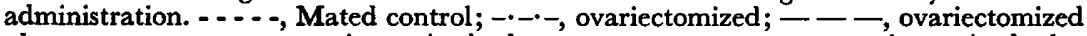
plus oestrogen; _- ovariectomized plus progesterone; $\cdots \cdots$, ovariectomized plus oestrogen and progesterone. 
response relationship. This adrenergic alpha receptor response was depressed 31 to $43 \%$ (average $39 \%$ ) 3 to 4 weeks after ovariectomy. The stimulatory effect of adrenaline returned to control levels following treatment with oestrogen or a combination of oestrogen and progesterone.

Adrenergic beta receptor activation with the injection of isoprenaline suppressed isthmic perfusion resistance at all three experimental levels. As shown in Table 1, the inhibitory response did not compare in amplitude to the alpha stimulatory effect. The beta inhibition was reduced 20 to $40 \%$ (average $27 \%$ ) by ovariectomy (Text-fig. 2). Exogenous progesterone was more effective than oestrogen in sustaining the oviduct's response to isoprenaline. The drug response after combined treatment with both ovarian hormones was above that observed in control oviducts.

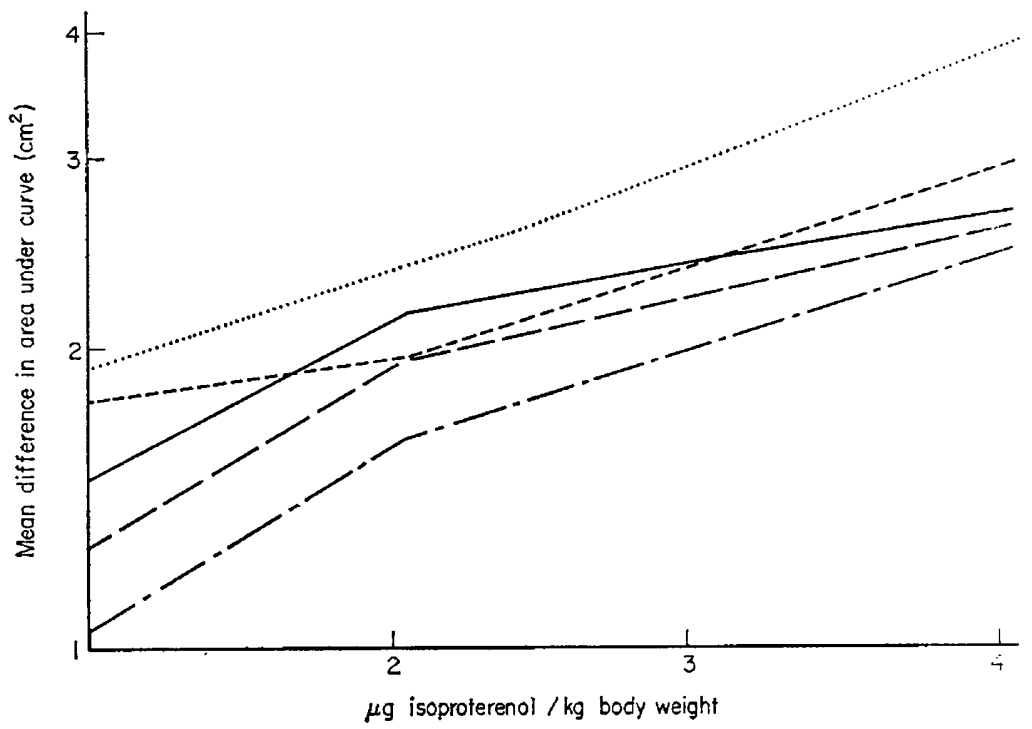

TEXT-FIG. 2. Ghanges in area under curve for oviduct tracings caused by isoproterenol

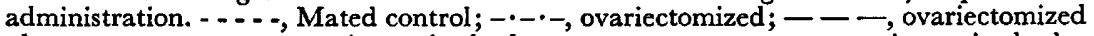
plus oestrogen; — ovariectomized plus progesterone; $\cdots \cdots$, ovariectomized plus oestrogen and progesterone.

\section{DISCUSSION}

Constant rate perfusion through the tubal isthmus in anaesthetized rabbits provided a means of evaluating the response of the tubal musculature to adrenergic drugs after treatment with hormones. Previous studies (G. R. Howe \& D. L. Black, unpublished data) with permanent oviducal cannulation in non-anaesthetized does were invalid because of displacement of the perfusion catheter and/or constant changes in the animal's neurological state. It is true, however, that the open-ended perfusion cannulae used in the present study have certain inherent disadvantages such as the possibility of occlusion from oviducal movements or interference with tubal secretions (Greenwald, 1963; Brundin, 1964). On the other hand, this technique was sufficient for illustrating 
a dose-response relationship between muscular activity and adrenergic drugs. More recent observations by Talo \& Brundin (1970) suggest that perfusion rates greater than $5.8 \mu \mathrm{l} / \mathrm{min}$ might contribute, in part, towards the overall muscular activity through muscle stretch.

Contrary to the concept that oestrogen is essential for contractility in the rabbit oviduct (Glemens, Shih, Brick \& Callantine, 1970), the current study revealed that isthmic activity was increased approximately $43 \%$ within 3 to 4 weeks after ovariectomy. These observations are in agreement with Boling \& Blandau (1971) who noted that muscular activity increases with oestrogen withdrawal, and that this stimulation is increased by progestins. Likewise, the present data revealed that the overall activity of the tubal musculature in ovariectomized does was suppressed by oestrogen treatment. This would explain the increased oviduct motility 4 to $24 \mathrm{hr}$ after an injection of HCG (Salomy \& Harper, 1971) when there is an acute ovarian steroid withdrawal (Hilliard \& Eaton, 1971).

In the past few years, studies have shown that the adrenergic nervous system can stimulate oviducal motor activity (Brundin, 1965; Longley et al., 1968a). The present study indicated that the alpha adrenergic receptors in the tubal isthmus are stimulatory while the beta receptors are inhibitory. Ovariectomy reduced the oviduct's response to both adrenaline and isoprenaline. Through hormonal replacement, it was possible to show that the degree of alpha and beta activity was dependent upon oestrogen and progesterone, respectively. The predominance of alpha receptor activity in the rabbit oviduct is emphasized by the fact that oestrogen alone or in combination with autonomic drugs had the greatest influence on the position of ova $36 \mathrm{hr}$ after coitus (Longley et al., 1968b). The same study showed that phenoxybenzamine (an alpha receptor-blocking agent) effectively inhibits movement of ova through the oviduct. Increased muscle tonus might explain why high doses of oestrogen retard the rate of egg transport (Chang \& Harper, 1966).

\section{ACKNOWLEDGMENT}

This work was supported by U.S.P.H.S. grant HDO4189-03.

\section{REFERENCES}

BlAck, D. L. \& Asdell, S. A. (1958) Transport through the rabbit oviduct. Am. F. Physiol. 192, 63. Blandau, R. J. (1969) Gamete transport-comparative aspects. In: The Mammalian Oviduct, p. 129. Eds. E. S. E. Hafez and R. J. Blandau. University of Chicago Press, Chicago.

Bousng, J. L. (1969) Endocrinology of oviductal musculature. In: The Mammalian Oviduct, p. 163. Eds. E. S. E. Hafez and R. J. Blandau. University of Chicago Press, Chicago.

Boling, J. L. \& Blandau, R. J. (1971) Egg transport through the ampullae of the oviducts of rabbits under various experimental conditions. Biol. Reprod. 4, 174.

BRUNDIN, J. (1964) A functional block in the isthmus of the rabbit Fallopian tube. Acta physiol. scand. $60,295$.

BRundin, J. (1965) Distribution and function of adrenergic nerves in the rabbit Fallopian tube. Acta physiol. scand. 61, 203.

Grang, M. G. \& Harper, M. J. K. (1966) Effects of ethinyl estradiol on egg transport and development in the rabbit. Endocrinology, 78, 860 .

Glemens, L. E., Shim, Y., Brick, H. O. \& Gallantine, M. R. (1970) Physiological significance of $17 \beta$ estradiol binding in rabbit Fallopian tube. Fedn Proc. Fedn Am. Socs. exp. Biol. $29,249$. 
Greenwald, G. S. (1961) A study of the transport of ova through the rabbit oviduct. Fert. Steril. 12, 80. GREENWALD, G. S. (1963) In vivo recording of intraluminal pressure changes in the rabbit oviduct. Fert. Steril. 14, 666 .

HARPER, M. J. K. (1966) Hormonal control of transport of eggs in cumulus through the ampulla of the rabbit oviduct. Endocrinology, 78, 568.

Hilliard, J. \& EAton, L. W., JR (1971) Estradiol-17 $\beta$, progesterone and $20 \alpha$-hydroxypregn-4-en-3one in rabbit ovarian venous plasma. II. From mating through implantation. Endocrinology, 89, 522.

HowE, G. R. (1970) Study of egg transport in the rabbit using a freezing-clearing technique. $\mathcal{F}$. Reprod. Fert. 21, 399.

Longley, W. J. \& Black, D. L. (1968) Comparisons of methods for locating ova in the oviduct of the rabbit. F. Reprod. Fert. 16, 69.

Longley, W. J., Black, D. L. \& Gurrie, G. N. (1968a) Oviduct circular muscle response to drugs related to the autonomic nervous system. F. Reprod. Fert. 17, 95.

LONGLEY, W. J., BLACK, D. L. \& GURRIE, G. N. (1968b) Ovarian hormone control of ovum transport in the rabbit as influenced by autonomic drugs. F. Reprod. Fert. 17, 579.

Rosenblum, I. \& Stein, A. A. (1966) Autonomic responses of the circular muscles of the isolated human Fallopian tube. Am. 7. Physiol. 210, 1127.

Salomy, M. \& HarPer, M. J. (1971) Gyclical changes of oviduct motility in rabbits. Biol. Reprod. 4, 185.

TALo, A. \& Brundin, J. (1970) Muscular activity in the rabbit oviduct: a combination of electric and mechanic recordings. Biol. Reprod. 5, 67. 